\title{
Commentary: Tissue is the issue-Bioprosthetic versus mechanical valves in dialysis-dependent patients
}

\author{
Alexander P. Nissen, MD, and Tom C. Nguyen, MD
}

\footnotetext{
From the Department of Cardiothoracic and Vascular Surgery, University of Texas Health Science Center Houston, McGovern Medical School, Houston, Tex.

Disclosures: T.C.N. is a consultant for Edwards Lifesciences, Abbott, and LivaNova. A.P.N. has nothing to disclose with regard to commercial support.

Received for publication Dec 10, 2018; accepted for publication Dec 10, 2018; available ahead of print Feb 2, 2019.

Address for reprints: Tom C. Nguyen, MD, 6400 Fannin St, Suite 2850, Houston, TX 77030 (E-mail: tom.c. nguyen@gmail.com).

J Thorac Cardiovasc Surg 2019;158:59-60

0022-5223/\$36.00

Copyright (C) 2019 Published by Elsevier Inc. on behalf of The American Association for Thoracic Surgery https://doi.org/10.1016/j.jtcvs.2018.12.097
}

For dialysis-dependent patients requiring valve replacement, controversy remains as to whether mechanical or tissue valves are preferred. Historically, guidelines ${ }^{1}$ have recommended mechanical valves in patients with endstage renal disease (ESRD) because of concern for calcific structural valve deterioration (SVD); however, limited survival of patients with ESRD requiring valve replacement ${ }^{2}$ has called such benefit into question.

In this issue of the Journal, Ikeno and colleagues ${ }^{4}$ present a cohort of 312 dialysis-dependent patients across 7 Japanese centers requiring either mechanical $(n=94)$ or bioprosthetic $(\mathrm{n}=218)$ valve replacement. Intermediate-term reoperation rates and survival were similar between mechanical and bioprosthetic groups and comparable to previous reports, ${ }^{3}$ whereas thromboembolic complications were increased among patients receiving mechanical valves. On subgroup analysis by valve position, increased thromboembolic complications were seen among patients undergoing mechanical versus bioprosthetic aortic valve replacement $(A V R)$, without differences among patients undergoing mitral valve replacement or double valve replacement. Ikeno and colleagues ${ }^{4}$ conclude that bioprosthetic valve replacement in patients with ESRD may reduce thromboembolic events without increased rates of SVD, and we congratulate them for their work.

One critique is the substantial heterogeneity of operations performed. Comparing bioprosthetic versus mechanical groups, rates for AVR $(83.9 \%$ vs $47.9 \% ; P<.001)$, mitral valve repair $(14.2 \%$ vs $4.3 \% ; P=.006)$, mitral valve replacement ( $10.6 \%$ vs $36.2 \% ; P<.001)$, and double valve replacement $(5.5 \%$ vs $16.0 \% ; P=.004)$ were each different. Propensity scoring may might have helped to account for these differences, although sample size might then have proved limiting. Although the generous approach to subject inclusion of Ikeno and colleagues ${ }^{4}$ increases statistical power for overall comparisons and possibly external validity to the greater dialysis-dependent population, it out.

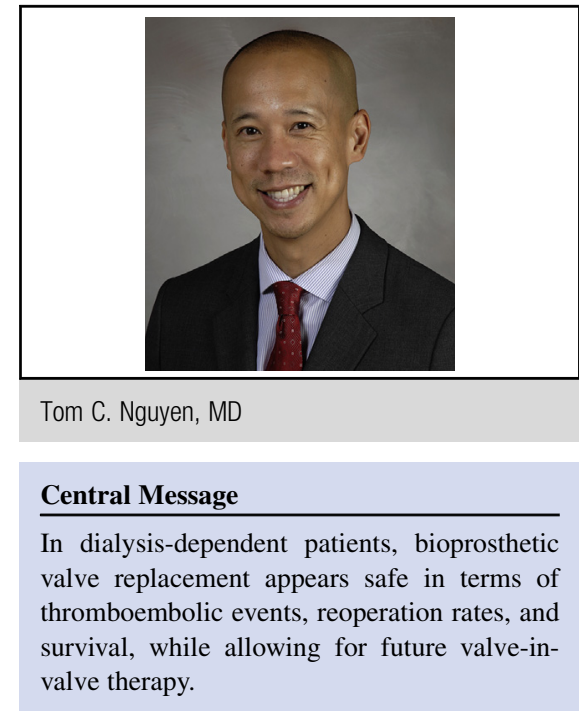

See Article page 48.

also imparts substantial bias, which they appropriately point

Reduced thrombotic complications also contradict the findings of Nakatsu and colleagues, ${ }^{5}$ who recently examined 491 dialysis-dependent patients requiring mechanical versus bioprosthetic AVR across 18 Japanese centers and found no difference in thromboembolic events at 5-year follow-up. In contrast to Ikeno and colleagues ${ }^{4}$ and colleagues, Nakatsu and colleagues ${ }^{5}$ focused on patients requiring AVR, and their larger sample size may have allowed them better to capture a representative sample of this specific subpopulation, without necessarily offering generalizability to patients requiring mitral valve replacement or double valve replacement.

One caveat not addressed in either publication is the possibility for valve-in-valve ( $\mathrm{ViV}$ ) transcatheter aortic and/or mitral valve replacement for postoperative SVD. ViV therapy is an option in high-risk patients, and ESRD was present in approximately half of patients treated with $\mathrm{ViV}$ aortic and mitral $^{7}$ valve replacement in studies affirming the safety and efficacy of these techniques. Thinking ahead, an added benefit of initial bioprosthetic valve replacement in patients with ESRD is that ViV options remain available should evidence of SVD arise. Conversely, mechanical valve dysfunction after replacement compels patients with ESRD to undergo a high-risk open reoperation. 
Ikeno and colleagues ${ }^{4}$ add to the growing body of literature that bioprosthetic valve replacement in dialysisdependent patients is safe,,$^{3-5}$ also suggesting reduced thromboembolic complications with this approach, and we commend them for their work. In patients with ESRD, when tissue is the issue, perhaps bioprosthetic valves should be favored at the time of initial replacement and this issue revisited for $\mathrm{ViV}$ treatment of postoperative bioprosthetic SVD. It appears that tissue should be the issue when dealing with patients with ESRD requiring valve replacements.

\section{References}

1. Bonow RO, Carabello B, de Leon AC, Edmunds LH Jr, Fedderly BJ, Freed MD, et al. ACC/AHA guidelines for the management of patients with valvular heart disease. Executive summary. A report of the American College of Cardiology/American Heart Association task force on practice guidelines (committee on management of patients with valvular heart disease). J Heart Valve Dis. 1998;7: $672-707$.
2. Thourani VH, Sarin EL, Kilgo PD, Lattouf OM, Puskas JD, Chen EP, et al. Shortand long-term outcomes in patients undergoing valve surgery with end-stage renal failure receiving chronic hemodialysis. J Thorac Cardiovasc Surg. 2012;144: $117-23$.

3. Williams ML, Bavaria JE, Acker MA, Desai ND, Vallabhajosyula P, Hargrove WC, et al. Valve selection in end-stage renal disease: should it always be biological? Ann Thorac Surg. 2016;102:1531-5.

4. Ikeno Y, Mukohara N, Fukumura Y, Tobe S, Gan K, Obo H, et al. Outcomes of valve replacement with mechanical prosthesis versus bioprosthesis in dialysis patients: a 16-year multicenter experience. J Thorac Cardiovasc Surg. 2019;158: 48-56.e4.

5. Nakatsu T, Minakata K, Tanaka S, Minatoya K, PROGRESS-Kyoto Investigators. Intermediate-term outcomes of aortic valve replacement with bioprosthetic or mechanical valves in patients on hemodialysis. J Thorac Cardiovasc Surg. 2019;157: 2177-86.e3.

6. Dvir D, Webb J, Brecker S, Bleiziffer S, Hildick-Smith D, Colombo A, et al. Transcatheter aortic valve replacement for degenerative bioprosthetic surgical valves: results from the global valve-in-valve registry. Circulation. 2012;126: 2335-44.

7. Cheung A, Webb JG, Barbanti M, Freeman M, Binder RK, Thompson C, et al. 5-year experience with transcatheter transapical mitral valve-in-valve implantation for bioprosthetic valve dysfunction. J Am Coll Cardiol. 2013;61: 1759-66. 